\title{
ANALYSIS OF THE MICROSTRUCTURE OF AN AZ31/AA1050/AA2519 LAMINATE PRODUCED USING THE EXPLOSIVE-WELDING METHOD
}

\author{
ANALIZA MIKROSTRUKTURE LAMINATA AZ31/AA1050/AA2519, \\ IZDELANEGA Z METODO EKSPLOZIJSKEGA VARJENJA
}

\author{
Marcin Wachowski ${ }^{1 *}$, Robert Kosturek ${ }^{1}$, Lucjan Śnieżek ${ }^{1}$, Sebastian Mróz ${ }^{2}$, Michal Gloc ${ }^{3}$, \\ Agnieszka Krawczyńska ${ }^{3}$, Marcin Malek $^{4}$ \\ ${ }^{1}$ Military University of Technology, Faculty of Mechanical Engineering, 2 Generala Witolda Urbanowicza Street, Warsaw, Poland \\ ${ }^{2}$ Czestochowa University of Technology, Faculty of Production Engineering and Materials Technology, 19 Aleja Armii Krajowej Street, \\ Częstochowa, Poland \\ ${ }^{3}$ Warsaw University of Technology, Faculty of Materials Science and Engineering, 141 Woloska Street, Warsaw, Poland \\ ${ }^{4}$ Militrary University of Technology, Faculty of Civil Engineering and Geodesy, 2 Generala Witolda Urbanowicza Street, 00-908 Warsaw, \\ Poland
}

Prejem rokopisa - received: 2018-07-15; sprejem za objavo - accepted for publication: 2018-11-15

doi:10.17222/mit.2018.151

\begin{abstract}
Explosive welding is a solid-state process used for the metallurgical joining of two or more dissimilar metals. In this process, the energy of controlled detonation is utilized to accelerate one metal plate into another. As a result of the collision, an atomic bond is formed. This paper describes a study of a laminate based on the AZ31 magnesium alloy, the AA1050 aluminum alloy and the AA2519 aluminum alloy. The test material was obtained using the method of explosive welding in a direct configuration AZ31/AA2519, with the intermediate layer made of AA1050 alloy previously rolled on the AA2519. The microstructure of the bonds was evaluated using scanning electron (SEM) and transmission electron microscopes with the SAED technique, while the chemical composition was assessed using energy-dispersive spectroscopy (EDS). The mechanical properties were examined with mini-specimen tensile tests and microhardness measurements. Between the joined aluminum alloys, an oxide layer was observed. It was also reported that the obtained joint is free of brittle intermetallic phases.

Keywords: Explosive welding, microstructure, AZ31, AA2519
\end{abstract}

Eksplozijsko varjenje je proces spajanja v trdnem stanju, ki se uporablja za metalurško spajanje dveh ali več različnih kovin ali zlitin. V tem procesu se izkorišča energija kontrolirane detonacije za pospešeno spajanje ene kovinske plošče z drugo. Kot rezultat izvedene detonacije je nastanek atomske vezi med obema materialoma. Avtorji so raziskovali nastanek laminata med Mg zlitino AZ31 ter Al zlitinama AA1050 in AA2519. Testni material so izdelali z metodo eksplozijskega varjenja v direktni konfiguraciji AZ31/AA2519 z vmesno plastjo, narejeno iz zlitine AA1050, ki je bila predhodno navaljana na zlitino AA2519. Mikrostrukturo eksplozijskega spoja so okarakterizirali z vrstičnim elektronskim mikroskopom (SEM) in presevnim elektronskim mikroskopom, opremljenim s tehniko SAED, medtem ko je bila mikrokemijska analiza izvršena z energijsko disperzijsko spektroskopijo (EDS). Za določitev mehanskih lastnosti so izdelali miniaturne natezne preizkušance. Določili so tudi mikrotrdoto izdelanih spojev. Na meji spoja Al zlitin so opazili oksidno plast. Poročajo tudi, da na izdelanem spoju ni opaziti krhkih intermetalnih faz.

Ključne besede: eksplozijsko varjenje, mikrostruktura, AZ31, AA2519

\section{INTRODUCTION}

One of the most promising engineering materials in terms of an improvement in the ballistic properties of materials used for armor are metallic laminates, where the components of the laminate have different chemical compositions and structures. ${ }^{1-3}$ The configuration of the materials restricts the method of their joining. The explosive-welding method makes it possible to produce laminates made of different materials that are typically impossible to join using conventional methods of welding. ${ }^{4-8}$ Joining by explosion belongs to the group of pressure welding and is used in the production of application components where high strength, wear resistance, corrosion resistance or strength of the applied surface layer of the material is required.5,9-12 This method significantly reduces the cost of the materials and makes it possible to connect materials types that would otherwise be difficult to join. An explosion can weld almost all metals, but in some cases a third layer might be used in order to bond materials that differ greatly in terms of their mechanical properties. ${ }^{13,14}$ The aim of this study was to present original results and the progress in explosively welded AZ31/AA1050/AA2519 laminates, which have potential applications in the military industry. Detailed studies were carried out in order to characterize and better understand the microstructures at the bonding zones. The AA2519 was cladded with the AA1050 alloy in a rolling process in order to provide better weldability with the AZ31 alloy using the explosive welding method.

*Corresponding author e-mail:

marcin.wachowski@wat.edu.pl 


\section{EXPERIMENTAL PART}

The aim of this research was to study the microstructure of explosively welded sheets of magnesium alloy AZ31, the aluminum alloy AA2519 and an additional interlayer made of the aluminum alloy AA1050. The chemical composition of the welded plates is presented in Table 1. The thickness of the welded elements was equal to $5 \mathrm{~mm}$ for the AZ31, $5 \mathrm{~mm}$ for the AA2519 and $1 \mathrm{~mm}$ for the AA1050. The explosive-welding process was performed in the EXPLOMET High-Energy Techniques Works, a Polish company concerned with explosive metalworks. As an explosive material, a mixture of ammonium nitrate fuel oil (ANFO) was used. A parallel configuration of the welding system was used to achieve a bond. The scheme of the explosive-welding system is presented at Figure 1.

Table 1: Chemical composition of the welded plates

\begin{tabular}{|c|c|c|c|c|c|c|c|c|}
\hline & \multicolumn{7}{|c|}{ Chemical composition, $w / \%$} \\
\hline \multirow{2}{*}{ AZ31 } & $\mathrm{Al}$ & $\mathrm{Zn}$ & $\mathrm{Mn}$ & $\mathrm{Si}$ & $\mathrm{Cu}$ & $\mathrm{Ca}$ & $\mathrm{Fe}$ & $\mathrm{Mg}$ \\
\cline { 2 - 10 } & $2.50<0.60<$ & 0.20 & 0.10 & 0.050 & 0.040 & 0.0050 & balance \\
\hline \multirow{2}{*}{ AA1050 } & $\mathrm{Fe}$ & $\mathrm{Si}$ & $\mathrm{Cu}$ & $\mathrm{Mg}$ & $\mathrm{Mn}$ & $\mathrm{Zn}$ & $\mathrm{Ti}$ & $\mathrm{Al}$ \\
\cline { 2 - 10 } & 0.4 & $0.25<$ & $0.05<$ & 0.18 & $0.05<$ & $0.07<$ & $0.05<$ & balance \\
\hline \multirow{2}{*}{ AA2519 } & $\mathrm{Fe}$ & $\mathrm{Si}$ & $\mathrm{Cu}$ & $\mathrm{Mg}$ & $\mathrm{Zr}$ & $\mathrm{Sc}$ & $\mathrm{Ti}$ & $\mathrm{Al}$ \\
\cline { 2 - 9 } & 0.08 & 0.06 & 5.77 & 0.18 & 0.2 & 0.36 & 0.04 & balance \\
\hline
\end{tabular}

In order to investigate the microstructure of the joints the sample was examined using a scanning electron microscope (JEOL JSM 6610) with energy-dispersive $\mathrm{X}$-ray spectroscopy (EDS) and a back-scattered electron (BSE) detector. Metallographic observations were carried out using samples cut from the plate in the direction perpendicular to the welding direction. The samples were prepared using a HITACHI IM4000 ion polishing system. The TEM/SAED analysis was performed using a JEOL JEM-1200 transmission electron microscope. The microhardness measurements were performed across the two joints' boundaries using a Vickers tester with a $100-\mathrm{g}$ load and interval of $100 \mu \mathrm{m}$ in the magnesium AZ31, the aluminum AA1050 and the aluminum AA2519. In order to define the mechanical properties, tensile tests using mini-specimens were carried out. The specimen dimensions are shown in Figure 2. Fractography was performed using an OLYMPUS LEXT OLS41000 laser confocal microscope.

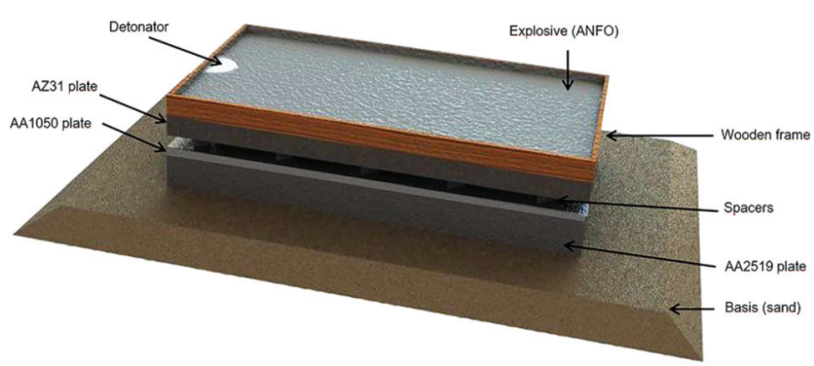

Figure 1: Scheme of the explosive welding system

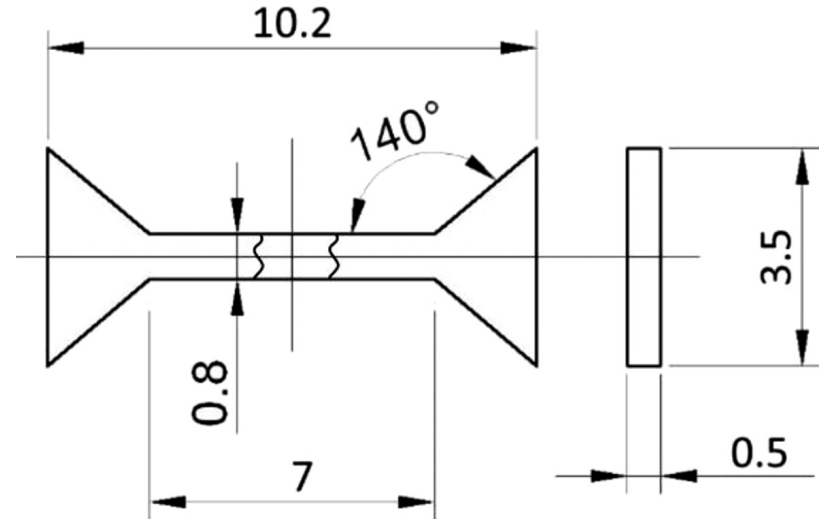

Figure 2: Mini-specimen dimensions

\section{RESULTS}

Macroscopic observations revealed that the AA1050/ AZ31 joint was successfully created. Observations confirmed the good quality, without macroscopic voids or delamination. It is the result of removing the initial oxide layers during the joining process. An SEM image of the explosively welded zones of the AZ31/AA1050/AA2519 laminate is shown in Figure 3.

Microscopic observation of the AA1050/AA2519 joint revealed the flat-shaped geometry of the joint, without defects and delamination. In the AA1050 plate, the grains have an equiaxial shape with an average size of $2 \mu \mathrm{m}$ (Figure 4A). Their size decreases to $500 \mathrm{~nm}$ adjacent to the bonding zone. This is a result of the severe plastic deformation during the rolling process. The scanning electron microscopy results revealed the presence of high-oxygen-concentration areas in the AA1050/AA2519 joint interface with a width of about 2-4 $\mu \mathrm{m}$. The presence of the oxide layer between the AA1050 and AA2519 alloys is connected with the cladding process performed by the rolling. The EDS mapping results revealed the presence of aluminum, copper and oxide (Figure 4B). The EDS mapping also revealed $\mathrm{Al}_{2} \mathrm{Cu}$ participates in the AA2519 microstructure.

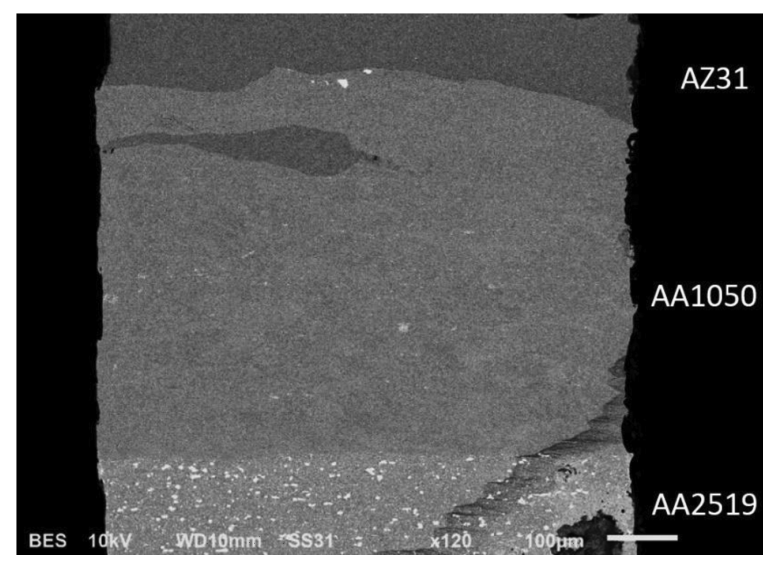

Figure 3: Scanning electron microscopy image of the joints 

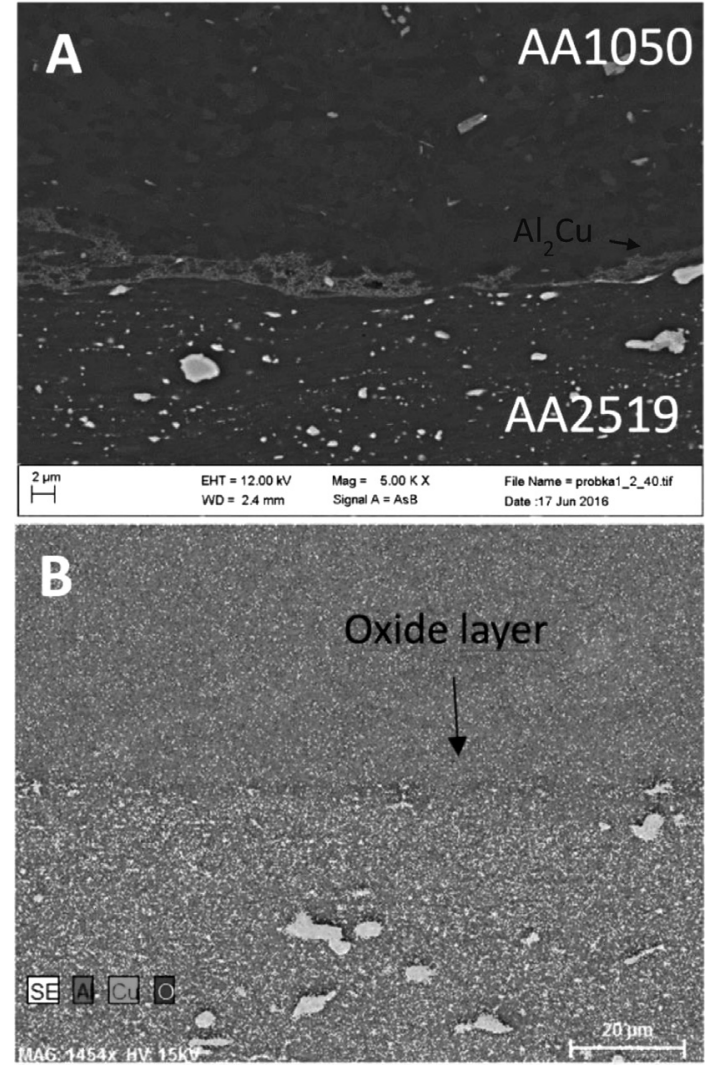

Figure 4: Image of the AA1050/AA2519 joint, A) SEM result, B) EDS mapping result
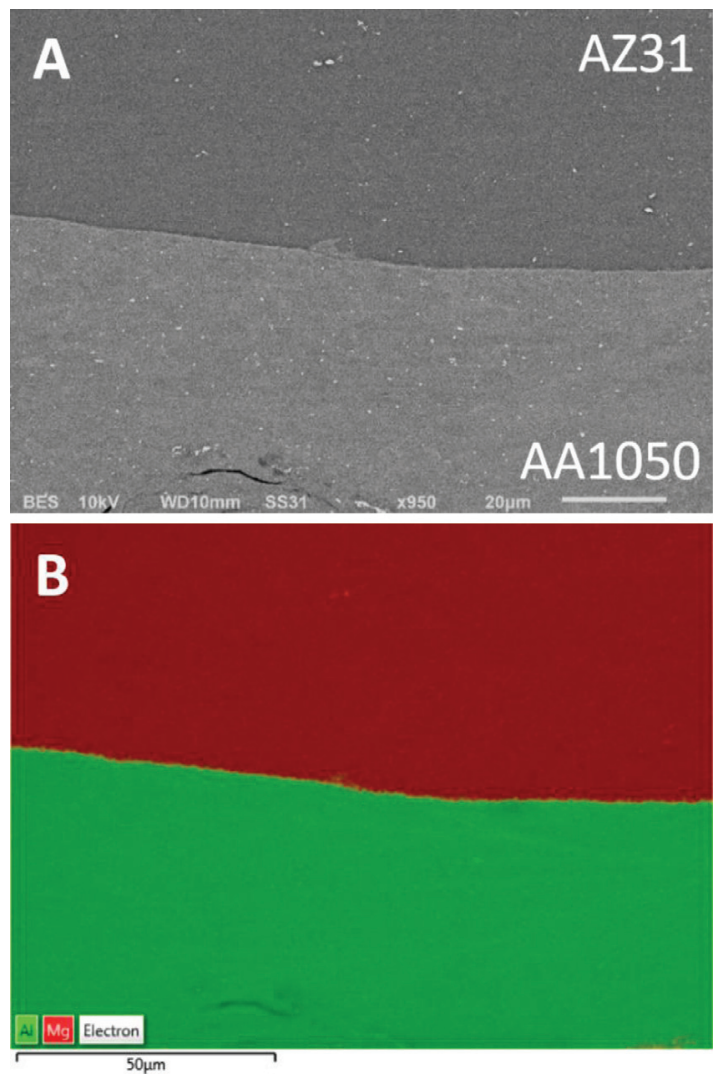

Figure 5: Image of the AZ31/AA1050 joint, A) SEM result, B) EDS mapping result

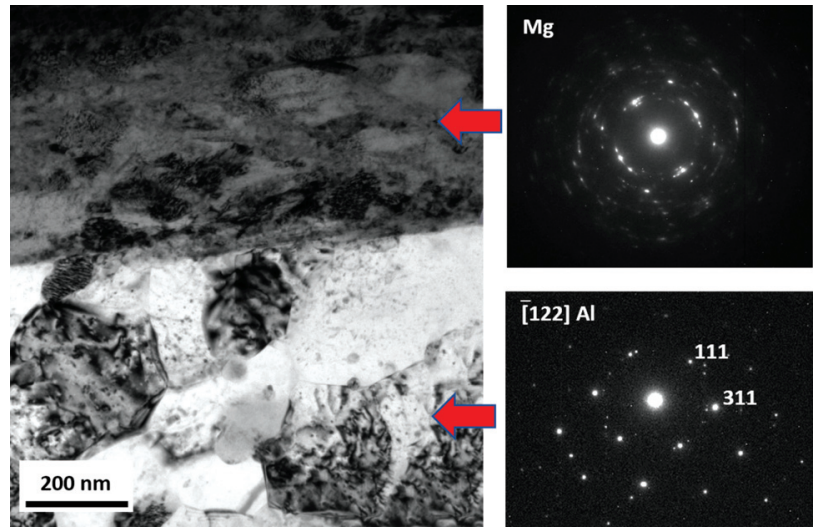

Figure 6: Transmission electron microscopy observation of the AZ31/AA1050 zone and the SAED analysis results

A microscopic observation of the AZ31/AA1050 explosively welded joint revealed a flat-shaped geometry of the joint without defects and delamination similar to the AA1050/AA2519 joint (Figure 5A). The scanning electron microscopy observation revealed a lack of melted areas, oxide layer and intermetallic phases in the bond zone of the AZ31/AA1050 joint. The EDS mapping results revealed the presence of aluminum and magnesium only (Figure 5B).

The transmission electron microscope observations (Figure 6) and the selected-area diffraction were performed in order to confirm the lack of melted zones or intermetallic phases in the AZ31/AA1050 bonding zone. The obtained pattern was compered to patterns for magnesium and aluminum. The TEM results revealed the high plastic deformation of the AZ31 near the joint and the equiaxed grains of the AA1050.

The microhardness measurement result is shown in Figure 7. It was found that local strengthening occurred in the joints to a distance of approximately $400 \mu \mathrm{m}$ into the magnesium alloy and $200 \mu \mathrm{m}$ into the AA2519 aluminum alloy. The maximum microhardness was measured near to the joint in the AA2519 plate (HV0,1 = 154). At a larger distance from the joint, the strengthening in both the AA2519 and AZ31 decreased, but did not reach the values of the base materials. In the case of AA1050, the strengthening was found in the whole cross-section of the material.

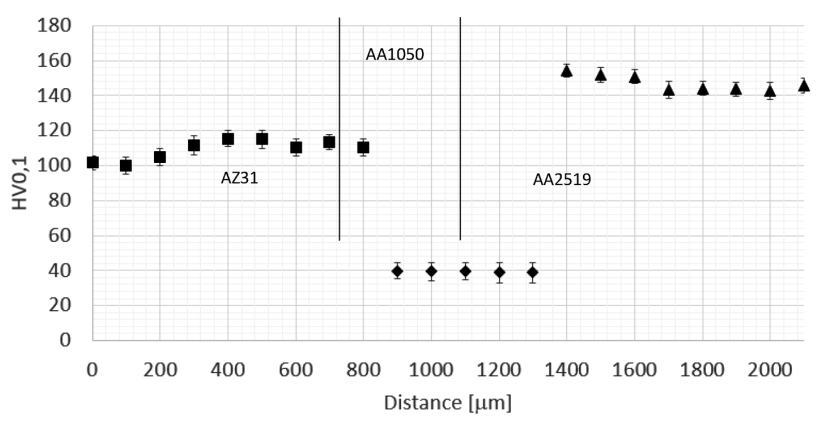

Figure 7: Microhardness profile for the explosively welded laminate 


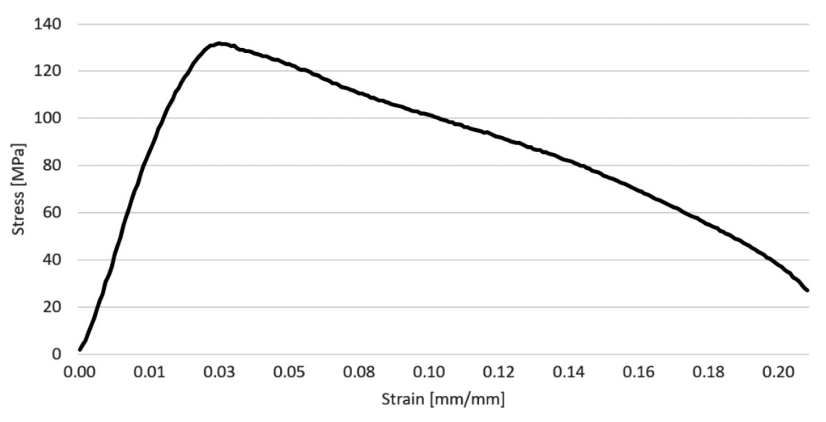

Figure 8: Stress-strain curve of mini-specimen tensile test results

The mini-specimen tensile tests were conducted at room temperature. Figure $\mathbf{8}$ gives the results for the tests conducted on the specimens. The test results give the minimum UTS (ultimate tensile strength) value at 131 MPa.

In order to investigate the crack propagation during the tensile test, the samples were observed after the test. Interesting results were obtained during examination of the joint surfaces in the samples that were stopped before failure. Plastic deformation during the tensile test started in the AA1050 layer, as shown in Figure 9. Failure of the material was observed in the central part of the AA1050, which means that the joints have higher strength than the intermediate layer.

\section{DISCUSSION}

The explosive welding technology allows us to obtain a joint between the AZ31 and the AA2519 that is cladded with AA1050. Scanning electron microscopy observations of the AZ31/AA1050 indicate a lack of joint imperfections, such as cracks and voids. The grain structure of the joined materials has anoticeable deformation texture, with severe plastic deformation of the compressed elongated grains directly next to the joint line. The results of the selected-area diffraction, as well as the EDS mapping, confirmed that no melted zone or intermetallic compounds occur in the AZ31/AA1050

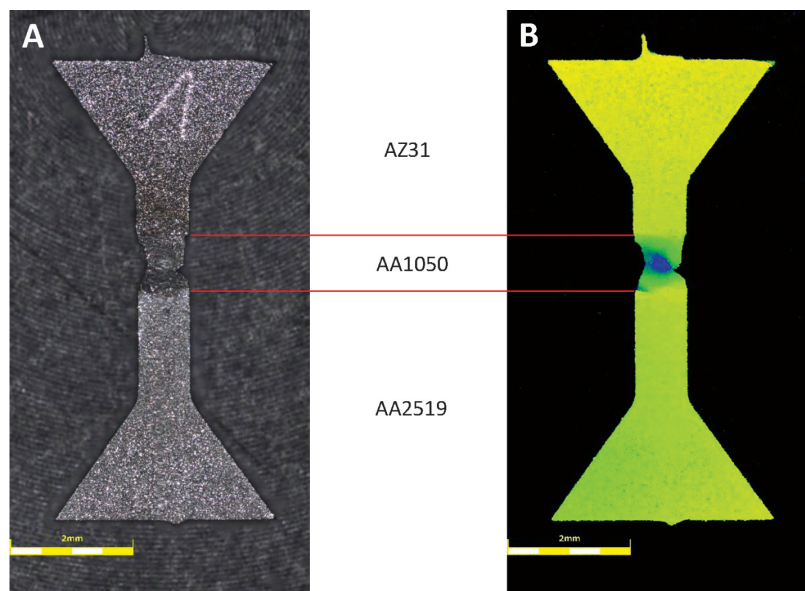

Figure 9: Fractography results. A) optical image, B) depth image explosively welded joint. On the other hand, the AA1050/AA2519 joint interface obtained by the rolling process is characterized by the presence of a thin oxide layer. The presence of the oxide layer near the bonding zone proves that jetting is not taking place during the roll-cladding, in contrast to the explosive welding process where the presence of a jet makes it possible to join clean surfaces without any impurities and oxides Both joints have an ultrafine-grained microstructure. The collision resulting from the explosion between the upper (AZ31) and lower (AA1050/AA2519) plates introduces a highly localized plastic deformation into plates, which causes grain fragmentation and the jetting provides an oxide-free joint interface. The layer AA1050 exhibits the lowest strength of all the components of the laminate. Fractography observations reveal the lack of delamination of the joints during the tensile test and the presence of failure in the central part of the intermediate layer. On the other hand, the use of a roll-cladded interlayer is necessary to join the AZ31 with the AA2519 using explosive welding.

\section{CONCLUSIONS}

The results demonstrated that an AZ31/AA1050/ AA2519 laminate can be successfully produced by the roll-cladding of AA2519 with AA1050, and then by explosive welding with the AZ31 alloy. Both the AZ31/AA1050 and the AA1050/AA2519 joints exhibit a good quality of bonding without voids and delamination. The joint interfaces are characterized by a flat-shape geometry, as well as having a lack of melted zones. The presence of an oxide layer on the AA1050/AA2519 joint interface was reported. The mechanical properties of the laminate are mainly dependent on the applied interlayer made of AA1050. The AA1050 layer reveals the lowest strength of all the components of the laminate, and it is the material where the crack propagation and delamination are initiated. Unfortunately, the application of an interlayer is necessary to obtain a joint between the AZ31 and AA2519 using the explosive welding method.

\section{Acknowledgment}

This work uses results of the research from the project co-financed from Polish Ministry of National Defence no. PBG/13-998. This work was also supported by the Project PBS2/A5/35/2013 funded by the National Research and Development Centre.

\section{REFERENCES}

${ }^{1}$ H. Gower, D. S. Cronin, A. Plumtree, Ballistic impact response of laminated composite panels, Inter. J. of Imp. Eng., 35 (2008), 1000-1008, doi:10.1016/j.ijimpeng.2007.07.007

${ }^{2}$ A. R. Najihah, M. F. Abdullah, A. Sarwat, W. Zamri, W. F. Hakim, S. Zainuddin, Characterising ballistic limits of lightweight laminated- 
structure as a protective panel for armoured vehicle, J. of Mech. Eng., (2017), 20-34

${ }^{3}$ A. Bhatnagar, Lightweight Ballistic Composites: Military and LawEnforcement Applications, Woodhead Publishing 2016, doi:10.1016/ C2014-0-03657-X

${ }^{4}$ K. Topolski, P. Wieciński, Z. Szulc, A. Galka, H. Grabacz, Progress in the characterization of explosively joined Ti/Ni bimetals, Mat. \& Des., 63 (2014), 479-487, doi:10.1016/j.matdes.2014.06.046

${ }^{5}$ F. Findik, Recent developments in explosive welding, Mat. \& Des., 32 (2011), 1081-1093, doi:10.1016/j.matdes.2010.10.017

${ }^{6}$ D. M. Fronczek, R. Chulist, L. Litynska-Dobrzynska, S. Kac, N Schell, Z. Kania, Z. Szulc, J. Wojewoda-Budka, Microstructure and kinetics of intermetallic phase growth of three-layered A1050/ AZ31/A1050 clads prepared by explosive welding combined with subsequent annealing, Mat. \& Des., 130 (2017), 120-130, doi:10.1016/j.matdes.2017.05.051

${ }^{7}$ D. M. Fronczek, R. Chulist, Z. Szulc, J. Wojewoda-Budka, Growth kinetics of TiAl3 phase in annealed Al/Ti/Al explosively welded clads, Mat. Let., 198 (2017), 160-163, doi:10.1016/j.matlet.2017. 04.025

${ }^{8}$ L. Čížek, D. Ostroushko, E. Mazancová, Z. Szulc, R. Molak, M. Wachowski, M. Prażmowski, Structure and properties of sandwich material steel Cr13Ni10+ Ti after explosive cladding, Metall. J., 62 (2009), 110-112
${ }^{9}$ R. Kosturek, M. Najwer, P. Nieslony, M. Wachowski, Effect of heat treatment on mechanical properties of inconel 625/Steel P355NH bimetal clad plate manufactured by explosive welding, Adv. in Man., (2018), 681-686, doi:10.1007/978-3-319-68619-6_65

${ }^{10}$ N. Kahraman, B. Gülenç, F. Findik, Joining of titanium/stainless steel by explosive welding and effect on interface. J. of Mat. Proc. Tech., 169 (2005), 127-133, doi:10.1016/j.jmatprotec.2005.06.045

${ }^{11}$ M. X. Xie, X. T. Shang, L. Zhang, Q. Bai, T. T. Xu, Interface characteristic of explosive-welded and hot-rolled TA1/X65 bimetallic plate, Metals, 8 (2018), 159, doi:10.3390/met8030159

${ }^{12}$ A. Y. Malakhov, L. B. Perbukhin, I. Saikov, V. B. Vikhman, Explosion welding of high-strength bimetallic materials with a cladding layer based on niobium and nickel-cobalt alloys, Weld. Int., 29 (2015), 1-4, doi:10.1080/09507116.2014.986887

${ }^{13}$ J. Maliutina, V. Mali, A. Bataev, I. Bataev, K. A. Skorokhod, Explosive Welding of Titanium With Stainless Steel Using Bronze Tantalum as Interlayer. $20149^{\text {th }}$ IFOST, Bangladesh 2014, 436-439, doi:10.1109/IFOST.2014.6991157

${ }^{14}$ P. Manikandan, K. Hokamoto, M. Fujita, K. Raghukandan, R. Tomoshige, Control of energetic conditions by employing interlayer of different thickness for explosive welding of titanium/304 stainless steel, J. of Mat. Proc. Tech., 195 (2008), 232-240, doi:10.1016/ j.jmatprotec.2007.05.002 